\title{
Development of a kinetic model for biological sulphate reduction with primary sewage sludge as substrate
}

\author{
HS van Wageningen, SW Sötemann, NE Ristow, MC Wentzel* and GA Ekama \\ Water Research Group, Dept. Civil Eng., Univ. of Cape Town, Rondebosch 7701, South Africa
}

\begin{abstract}
The Rhodes BioSURE ${ }^{\circledR}$ Process is a low-cost active treatment system for acid mine drainage (AMD) waters. Central to this process is biological sulphate reduction (BSR) using primary sewage sludge (PSS) as the electron donor and organic carbon source, with the concomitant reduction of sulphate to sulphide and production of alkalinity. To optimise the design, operation and control of (and research into) BSR with PSS, a mathematical kinetic model would be an invaluable aid. This study describes the development of such a kinetic model. A two-phase (aqueous/gas) physical, biological and chemical processes kinetic model for the methanogenic anaerobic digestion of sewage sludges has been proposed (UCTADM1). This model incorporates biological processes for sewage sludge hydrolysis/solubilisation (usually the rate-limiting step) and acidification, acetogenesis, and acetotrophic(clastic) and hydrogenotrophic methanogenesis. Additionally, the background weak acid/ base chemistry for water, carbonate, acetate, propionate, ammonium and phosphate species have been included, as well as the physical gas exchanges for carbon dioxide and ammonia. The compound $\mathrm{H}^{+}$is explicitly included in the model as a predictive parameter, with corresponding $\mathrm{pH}$ inhibition of the methanogenic bioprocesses. Using this model as a basis, it is extended to incorporate BSR. The stoichiometry and kinetics for the bioprocesses (growth and death) mediated by the propionate degrading, acetotrophic and hydrogenotrophic sulphate-reducing bacteria are formulated, including sulphide and $\mathrm{pH}$ inhibition. These bioprocesses produce and consume inter alia sulphate and sulphide acid/base species which are not present in the original UCTADM1 model. Accordingly, following the approach in the UCTADM1 model, chemical processes for these are included. Further, in the BSR model the end-product sulphide has a gaseous equilibrium not in the UCTADM1 model, and hence the physical gas exchange for sulphide is included. The BSR biological, chemical and physical processes are integrated with those of the UCTADM1 model, to give a complete kinetic model for competitive methanogenic and sulphidogenic anaerobic digestion with PSS as substrate. This model currently is being evaluated, by application to a series of experimental systems fed a mixture of PSS and sulphate, operated over a range of retention times and $\mathrm{pHs}$.
\end{abstract}

Keywords: biological sulphate reduction, primary sewage sludge, kinetic model

\section{Introduction}

Pollution of surface and groundwater resources as a result of mining activities is not unique to South Africa, but occurs in most countries where mining plays a crucial role in the economy. This pollution emanates mainly through the discharge, intentionally (e.g. pumping) or unintentionally (e.g. seepages), of acid main drainage (AMD) waters to the environment. AMD waters arise from the biological oxidation of pyrite exposed in mining operations, and are characterised by low $\mathrm{pH}$ (2 to 3$)$, high iron $(10$ to $6700 \mathrm{mg} / \ell$ ) and sulphate (3 000 to $30000 \mathrm{mg} / \ell$ ) (salinity) concentrations, and varying non-ferrous (usually heavy) metal (e.g. Al 50 to $2000 \mathrm{mg} / \ell$ ) and TDS (1 800 to 45000 $\mathrm{mg} / \ell$ ) concentrations (Christensen et al., 1996). Accordingly, treatment of AMD prior to discharge, to lessen the environmental impact, has received increasing attention, particularly in South Africa (Holtzhausen, 2005). This treatment requires neutralisation of the $\mathrm{pH}$ and removal of the metals (ferrous and non-ferrous) and sulphate.

Most conventional methods for AMD treatment include chemical and/or physical processes, such as precipitation (e.g. as barium sulphate, gypsum, Hammack et al., 1994) and/or membrane filtration, which tend to be expensive and require skilled

This paper was originally presented at the 2006 Water Institute of South Africa (WISA) Biennial Conference, Durban, South Africa, 21-25 May 2006.

* To whom all correspondence should be addressed.

용+2721 650-2583; fax:+2721 689-7471; e-mail: markw@,ebe.uct.ac.za operators for the installation and maintenance of the various unit processes and their elements (Furter, 2005). Biological sulphate reduction (BSR) is an attractive alternative or supplement to these processes. In BSR, sulphate is reduced biologically to produce sulphide, consuming protons which neutralises the $\mathrm{pH}$. The produced sulphide forms insoluble precipitates with the metals ions, removing these from solution (Ristow and Hansford, 2001). BSR requires an organic substrate to act as an election and carbon source; with acetic acid, the reaction is:

$$
\mathrm{CH}_{3} \mathrm{COOH}+2 \mathrm{H}^{+}+\mathrm{SO}_{4}^{2-} \rightarrow 2 \mathrm{CO}_{2}+\mathrm{H}_{2} \mathrm{~S}+2 \mathrm{H}_{2} \mathrm{O}
$$

Various organic substrates for BSR have been evaluated, such as producer gas, ethanol, methanol and lactate (Dill et al., 2001; Greben and Maree, 2000; Ristow and Hansford, 2001). The pure substrates have proven effective, but are costly. As a lower cost alternative, in the Rhodes BioSURE® process (Rose et al., 2002) for the active treatment for AMD waters, primary sewage sludge (PSS) has been proposed as substrate (electron donor and carbon source) for the central BSR unit process (Furter, 2005).

For this and similar treatment schemes, a kinetic model describing BSR with PSS would be a valuable aid for design, operation and control. Further, the model would be a valuable research tool, to improve understanding of the underlying fundamental processes and their interactions. Such a model would need to incorporate the kinetics and stoichiometry for the two-phase (aqueous/gas, solid to be considered in the future) chemical, physical and biological processes of importance in 
BSR with PSS. This paper describes the development of such a kinetic model. Currently the developed model is being validated, by applying it to simulate a series of experimental labscale systems which were fed a mixture of PSS and sulphate, operated over a range of retention times and $\mathrm{pH}$ values (Ristow et al., 2005).

\section{Existing kinetic models}

The approach taken to develop the kinetic model for BSR with PSS was to evaluate existing kinetic models in the literature, select the most suitable and to extend/modify/integrate these as required. Ristow and Hansford (2001) developed a kinetic model for BSR with PSS as substrate. In this model, the focus was on the biological processes, and the chemical and physical processes considered to be important in BSR were not explicitly included. In development of their model, Ristow and Hansford (2001) recognised that under steady state the hydrolysis of PSS was the rate-limiting step. However, they noted that for this process a variety of kinetic rate formulations and data incompatibilities were evident in the literature. From the available information they were not able to determine the most appropriate kinetic rate formulation for this crucial process. Due to these deficiencies and limitations, Ristow et al. (2005) undertook an extensive investigation to describe and model the PSS hydrolysis step, under methanogenic, sulphidogenic and acidogenic conditions. They concluded inter alia that BSR does not appear to influence the rate of PSS hydrolysis (implying that methanogenic rate formulations and rate constants can be applied under BSR conditions also) and that for simple steady state models first-order kinetics (which analytically are simpler to apply) for PSS hydrolysis are adequate, but for more extensive kinetic models surface saturation (Contois) kinetics would be more suitable (and are followed by Sötemann et al., 2005 , see below). Ristow et al. only included $\mathrm{pH}$ empirically, by adjusting the value for the rate constant according to $\mathrm{pH}$ and did not consider the kinetics for the reactions subsequent to the hydrolysis.

The IWA task group for mathematical modelling of anaerobic digestion processes developed Anaerobic Digestion Model No. 1 (ADM1, Batstone et al., 2002). In this model the substrate, in this case PSS, is characterised into carbohydrates, lipids and proteins. For PSS, such measurements are not routinely available. In contrast, in the model developed by Van Rensburg et al. (2001), and extended and modified by Sötemann et al. (2005) for methanogenic anaerobic digestion of sewage sludges, the sludge is characterised with the usual COD, TKN and VSS measurements and the carbon, hydrogen, oxygen and nitrogen ( $\mathrm{CHON})$ composition which can be readily derived from the listed measurements and model application. Van Rensburg et al. (2001) and Sötemann et al. (2005) integrated the biological kinetic processes for anaerobic digestion (AD) into a two-phase (aqueous/gas) subset of the three-phase mixed weak acid/base chemistry kinetic model of Musvoto et al. (1997). The model was calibrated and validated with data from the laboratory mesophilic anaerobic digesters of Izzett et al. (1992). The sewage sludge COD was found to be 32 to $36 \%$ un-biodegradable (depending on the kinetic formulation selected for the hydrolysis process) and to have a $\mathrm{C}_{3.5} \mathrm{H}_{7} \mathrm{O}_{2} \mathrm{~N}_{0.196}$ composition. For the selected hydrolysis kinetics (surface mediated reaction (Contois)), with a single set of kinetic and stoichiometric constants, reasonable correlation was obtained between predicted and measured results for all retention times for:
- COD, free and saline ammonia (FSA), short-chain fatty acids (SCFA), $\mathrm{H}_{2} \mathrm{CO}_{3}{ }^{*}$ alkalinity and (v) $\mathrm{pH}$ of the effluent stream, and

- $\mathrm{CO}_{2}$ and $\mathrm{CH}_{4}$ gases in the gas stream.

The measured composition of PSS from two Cape Town wastewater treatment plants ranged between $\mathrm{C}_{3.38} \mathrm{H}_{7} \mathrm{O}_{1.91} \mathrm{~N}_{0.21}$ and $\mathrm{C}_{3.91} \mathrm{H}_{7} \mathrm{O}_{2.04} \mathrm{~N}_{0.16}$. The predicted composition based on mass balances in model application was within $5 \%$ of the average measured composition, providing persuasive validation of the model.

Accordingly, the model of Sötemann et al. (2005) (UCTADM1) was selected as the basis for the development of the kinetic model for BSR with PSS as substrate. This would require development of the kinetics and stoichiometry for the biological, chemical and physical processes in BSR in two phases (aqueous/gas), and integration of these with UCTADM1, taking due cognisance of any interactions introduced with the integration. Essentially, this would result in a two-phase biological, chemical and physical processes model for the AD of PSS, with competitive methanogenesis and sulphidogenesis.

\section{Development of a kinetic model for BSR with PSS as substrate}

The kinetic model for BSR with PSS was developed and integrated into the UCTADM1 model in three parts. Part 1 developed the biological processes: For the biologically mediated processes, the PSS first requires hydrolysis/solubilisation (usually the rate limiting step) and acidification, mediated by the acidogenic group of organisms, in common with sewage sludge methanogenic AD systems. The products of these processes, the SCFA, can then enter into the methanogenic or sulphate reduction processes, which operate in competition. One end-product of BSR is sulphide, which is inhibitory to the methanogens, requiring that this inhibition be included.

Part 2 considered the aqueous chemistry and physical processes. The background acid/base chemistry was included because the biological processes consume and produce significant acid/base species, e.g. SCFA, sulphide and sulphate. Consumption and production of acid/base species will influence the $\mathrm{pH}$ established in the reactor, which in turn can influence the biologically mediated processes. Hence, $\mathrm{pH}$ needed to be incorporated directly into the model, as a model predictive parameter, and its interaction with the biological processes modelled. Some of the endproducts have gaseous equilibria (sulphide, carbon dioxide, ammonia and methane) so that these physical processes also required inclusion (the third solid phase was not included at this stage).

Finally, Part 3 considered the integration of the aqueous chemistry and physical processes with the biological processes and the BSR with UCTADM1.

\section{Biomass population biology}

The approach of Kalyuzhnyi et al. (1998) formed the basis for the kinetic model for the biology of sulphate reducing bacteria (SRB). Kalyuzhnyi et al. (1998) described an anaerobic reaction sequence by which substrates are transformed by the following 9 trophic groups of bacteria: 
Fermentative bacteria

(ii) Butyrate degrading acetogenic bacteria

(iii) Butyrate degrading SRB

(iv) Propionate degrading acetogenic bacteria

(v) Propionate degrading SRB

(vi) Acetotrophic methanogenic bacteria

(vii) Acetotrophic SRB

(viii) Hydrogenotrophic methanogenic bacteria

(ix) Hydrogenotrophic SRB
(Sugars $\rightarrow$ Acetate)

(Butyrate $\rightarrow$ Acetate)

(Buryrate $\rightarrow$ Acetate \& $\mathrm{H}_{2} \mathrm{~S}$ )

(Propionate $\rightarrow$ Acetate)

(Propionate $\rightarrow$ Acetate $\& \mathrm{H}_{2} \mathrm{~S}$ )

(Acetate $\rightarrow$ Methane $\& \mathrm{CO}_{2}$ )

(Acetate $\rightarrow \mathrm{H}_{2} \mathrm{~S} \& \mathrm{CO}_{2}$ )

$\left(\mathrm{H}_{2} \& \mathrm{CO}_{2} \rightarrow\right.$ Methane)

$\left(\mathrm{H}_{2} \rightarrow \mathrm{H}_{2} \mathrm{~S}\right)$
Of the 9 bacterial groups, of interest here are the four SRB groups only (i.e. iii, v, vii and ix), since BSR was to be integrated with the existing methanogenic and acetogenic UCTADM1 model of Sötemann et al. (2005), which already explicitly includes (i), (iv) and (viii). Butyrate degrading acetogenic (ii) and SRB (iii) groups were not incorporated into the model, as butyrate is not commonly encountered in significant concentrations in sewage sludge digestion systems. Accordingly, the process stoichiometry and kinetics for the four SRB groups were considered, for both growth and decay.

\section{Growth stoichiometry}

For each SRB group, by following the procedure of Sötemann et al. (2005) and taking the catabolic and anabolic stoichiometric reactions and adding these, the stoichiometry for the growth bioprocesses could be determined (Table 1). For example, for the propionate-degrading SRBs $\left(Z_{\mathrm{PS}}\right)$, the catabolic substrate utilisation is (Kalyuzhnyi et al., 1998):

$$
\begin{aligned}
& \mathrm{C}_{2} \mathrm{H}_{5} \mathrm{COOH}+\frac{3}{4} \mathrm{SO}_{4}^{2-}+\frac{3}{2} \mathrm{H}^{+} \\
& \rightarrow \mathrm{CH}_{3} \mathrm{COOH}+\frac{3}{4} \mathrm{H}_{2} \mathrm{~S}+\mathrm{CO}_{2}+\mathrm{H}_{2} \mathrm{O}
\end{aligned}
$$

For the anabolic organism growth of $\mathrm{Z}_{\mathrm{PS}}$, accepting the stoichiometric composition for biomass as $\mathrm{C}_{5} \mathrm{H}_{7} \mathrm{O}_{2} \mathrm{~N}$ (Sötemann et al., 2005):

$$
\begin{aligned}
& 3 \mathrm{C}_{2} \mathrm{H}_{5} \mathrm{COOH}+\mathrm{CO}_{2}+2 \mathrm{NH}_{4}^{+} . \\
& \rightarrow 2 \mathrm{C}_{5} \mathrm{H}_{7} \mathrm{O}_{2} \mathrm{~N}+4 \mathrm{H}_{2} \mathrm{O}+\mathrm{H}_{2}+2 \mathrm{H}^{+}
\end{aligned}
$$

Adding Eqs. [2] and [3] and solving in terms of the true yield $\mathrm{Y}_{\mathrm{PS}}$, gives the growth stoichiometry listed in Table 1 (see next page), Process $\mathrm{S} 1$ ( $\mathrm{H}_{2} \mathrm{O}$ excluded from Table 1, but implicit from the stoichiometry). Similarly, the growth stoichiometries were derived for the other two SRB groups, Acetotrophic SRB $\left(Z_{\mathrm{AS}}\right.$, Process S3) and Hydrogenotrophic SRB $\left(\mathrm{Z}_{\mathrm{HS}}\right.$, Process S5).

\section{Endogenous decay stoichiometry}

It was assumed that organism death/decay for the SRB groups is the same as for the bacterial groups in the UCTADM1 model, and therefore the same approach was followed here. In UCTADM1 and in this SRB model, it was assumed that the organism mass is represented by the $\mathrm{C}_{5} \mathrm{H}_{7} \mathrm{O}_{2} \mathrm{~N}$ formulation. In endogenous decay, this organism mass transforms to biodegradable particulate $\operatorname{COD}\left(\mathrm{S}_{\mathrm{bp}}\right)$; due to the low anaerobic organism yield and endogenous decay rates, it was accepted that generation of endogenous residue was small and could be neglected. Initially it was accepted that the $\mathrm{S}_{\mathrm{bp}}$ formu- lation is $\mathrm{C}_{3.5} \mathrm{H}_{7} \mathrm{O}_{2} \mathrm{~N}_{0196}$, as determined by Sötemann et al. (2005). The COD/VSS ratio for $\mathrm{C}_{5} \mathrm{H}_{7} \mathrm{O}_{2} \mathrm{~N}=1.413 \mathrm{mgCOD} /$ $\mathrm{mg}$ VSS and $1 \mathrm{~mol} \mathrm{C}_{5} \mathrm{H}_{7} \mathrm{O}_{2} \mathrm{~N} \sim 160 \mathrm{mgCOD}$. Therefore, $160 \mathrm{~g}$ organism COD is $102.17 \mathrm{gVSS}$ organisms which equates to $1.219 \mathrm{~mol} \mathrm{C}_{3.5} \mathrm{H}_{7} \mathrm{O}_{2} \mathrm{~N}_{0.196}\left(\mathrm{COD} / \mathrm{VSS}\right.$ ratio of $\mathrm{C}_{3.5} \mathrm{H}_{7} \mathrm{O}_{2} \mathrm{~N}_{0.196}=$ $1.566 \mathrm{mgCOD} / \mathrm{mgVSS})$. Accordingly, endogenous decay of the organisms was represented by the following equation:

$$
\begin{aligned}
& \mathrm{C}_{5} \mathrm{H}_{7} \mathrm{O}_{2} \mathrm{~N}+1.905 \mathrm{H}_{2} \mathrm{O} \\
& \rightarrow 1.219 \mathrm{C}_{3.5} \mathrm{H}_{7} \mathrm{O}_{2} \mathrm{~N}_{0.196}+0.7335 \mathrm{CO}_{2}+0.761 \mathrm{NH}_{3}
\end{aligned}
$$

The stoichiometry for endogenous decay was taken directly from Eq. [4], see Tables 1 and 2.

If the generalised formulation for $\mathrm{S}_{\mathrm{bp}}$ of $\mathrm{C}_{\mathrm{X}} \mathrm{H}_{\mathrm{Y}} \mathrm{O}_{\mathrm{Z}} \mathrm{N}_{\mathrm{A}}$ is accepted, then the stoichiometry for endogenous decay can be extracted directly from Sötemann et al. (2005), see Table 3.

\section{Growth kinetic rates}

For the growth of SRB the principles of the kinetic rate descriptions were taken from Kalyuzhnyi et al. (1998), who modelled the bacterial growth of each SRB group using Monod kinetics, with simultaneous inhibition by $\mathrm{pH}$ and undissociated $\mathrm{H}_{2} \mathrm{~S}$. The undissociated $\mathrm{H}_{2} \mathrm{~S}$ inhibition was formulated as first order for all bacterial groups. Thus, the specific growth rate $\left(\mu_{\mathrm{j}}\right)$ equation for the SRB groups was expressed by Kalyuzhnyi et al. (1998) as:

$$
\mu_{\mathrm{j}}=\mu_{\max , j} \frac{\left[\mathrm{S}_{\mathrm{i}}\right] \mathrm{F}(\mathrm{pH})}{\mathrm{K}_{\mathrm{Sj}}+\left[\mathrm{S}_{\mathrm{i}}\right]}\left[1-\left(\frac{\left[\mathrm{H}_{2} \mathrm{~S}_{\mathrm{f}}\right.}{\mathrm{K}_{\mathrm{l}, \mathrm{j}}}\right)\right]\left(\frac{\left[\mathrm{SO}_{4}^{2-}\right]}{\mathrm{K}_{\mathrm{n}}+\left[\mathrm{SO}_{4}^{2-}\right]}\right)
$$

where:

$$
\begin{aligned}
& \mathrm{F}(\mathrm{pH})=\mathrm{pH} \text { inhibition function } \\
& \mu_{\max , \mathrm{j}}=\text { maximum specific growth rate for SRB group } \mathrm{j} \\
& {\left[\mathrm{S}_{\mathrm{i}}\right]=\text { organic substrate } \mathrm{i} \text { concentration }}
\end{aligned}
$$

TABLE 2

Stoichiometry for the endogenous respiration of all organism groups $\left(Z_{j}\right)$, with biodegradable particulate COD $\left(\mathrm{S}_{\mathrm{bp}}\right)$ formulation as $\mathrm{C}_{3.5} \mathrm{H}_{7} \mathrm{O}_{2} \mathrm{~N}_{0.196}$

\begin{tabular}{|c|c|c|c|c|}
\hline $\mathbf{Z}_{\mathbf{j}}$ & $\mathbf{H}_{2} \mathbf{C O}_{3}{ }^{*}$ & $\mathbf{N H}_{3}$ & \multicolumn{2}{|c|}{$\mathbf{S}_{\text {bp }}$} \\
\cline { 4 - 5 } & $\mathbf{m o l}$ & $\mathbf{m o l}$ & $\mathbf{g ~ C O D}$ & Mol \\
\hline-1 & 0.7335 & 0.761 & 160 & 1.219 \\
\hline
\end{tabular}

\section{TABLE 3}

Stoichiometry for the endogenous respiration of all organism groups $\left(Z_{j}\right)$ with biodegradable particulate $\operatorname{COD}\left(\mathrm{S}_{\mathrm{bp}}\right)$ formulation as $\mathrm{C}_{\mathrm{X}} \mathrm{H}_{\mathrm{Y}} \mathrm{O}_{Z} \mathrm{~N}_{\mathrm{A}}$

\begin{tabular}{|c|c|c|c|}
\hline $\begin{array}{c}\mathrm{NH}_{3} \\
\mathbf{m o l}\end{array}$ & $\begin{array}{c}\mathrm{H}_{2} \mathbf{C O}_{3}{ }^{*} \\
\mathbf{m o l}\end{array}$ & $\begin{array}{c}\mathbf{S}_{\mathrm{bp}} \\
\mathbf{m o l}\end{array}$ & $\begin{array}{c}\mathrm{Z}_{\mathrm{j}} \\
\mathbf{m o l}\end{array}$ \\
\hline$\frac{\mathrm{Y}+4 \mathrm{X}-2 \mathrm{Z}-23 \mathrm{~A}}{\mathrm{Y}+4 \mathrm{X}-2 \mathrm{Z}-3 \mathrm{~A}}$ & $\frac{5(\mathrm{Y}-2 \mathrm{Z}-3 \mathrm{~A})}{\mathrm{Y}+4 \mathrm{X}-2 \mathrm{Z}-3 \mathrm{~A}}$ & $\frac{20}{\mathrm{Y}+4 \mathrm{X}-2 \mathrm{Z}-3 \mathrm{~A}}$ & -1 \\
\hline
\end{tabular}




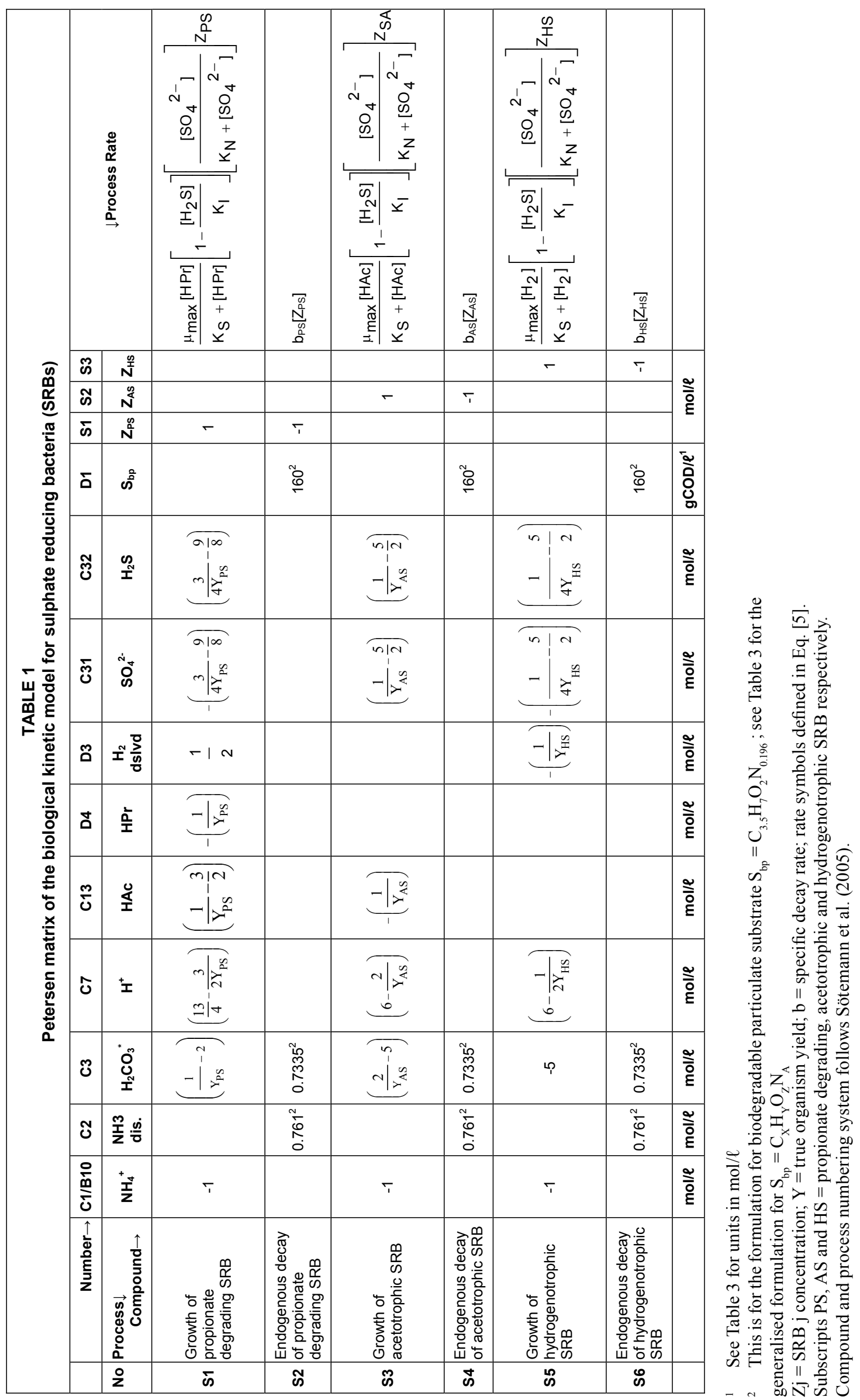




\begin{tabular}{|c|c|c|c|c|c|c|}
\hline \multicolumn{7}{|c|}{$\begin{array}{c}\text { TABLE } 4 \\
\begin{array}{c}\text { Values for SRB stoichiometric and kinetic constants used in the BSR } \\
\text { kinetic model (from Kalyuzhnyi et al., 1998) }\end{array}\end{array}$} \\
\hline & $\boldsymbol{\mu}_{\max } / \mathbf{d}$ & $\begin{array}{c}\mathrm{K}_{\mathrm{s}}^{1} \\
\mathrm{gCOD} / 1\end{array}$ & $\begin{array}{c}\mathrm{K}_{\mathrm{N}}{ }^{1} \\
\mathrm{gSO}_{4}{ }^{2-/ \ell}\end{array}$ & $\begin{array}{c}\mathrm{K}_{1}^{1} \\
\mathrm{gS} / \mathrm{e}\end{array}$ & $\begin{array}{c}\mathrm{Y}^{1} \\
\text { gVSS/gCOD }\end{array}$ & $\begin{array}{l}\mathrm{b} \\
/ \mathrm{d}\end{array}$ \\
\hline Propionate degrading SRBs & 0.583 & 0.295 & 0.0074 & 0.185 & 0.027 & 0.0185 \\
\hline Acetotrophic SRB & 0.612 & 0.024 & 0.01920 & 0.164 & 0.033 & 0.0275 \\
\hline Hydrogenotrophic SRB & 2.8 & $7 \mathrm{E}-05$ & 0.01920 & 0.550 & 0.050 & 0.0600 \\
\hline
\end{tabular}

${ }^{1}$ Constants to be converted to mole units on integration with UCTADM1, to ensure consistency in units.

$\mathrm{K}_{\mathrm{Sj}} \quad=$ Monod saturation constant for organic substrate

$\mathrm{K}_{\mathrm{I}, \mathrm{j}} \quad=$ inhibition constant for undissociated hydrogen sulphide $\left[\mathrm{H}_{2} \mathrm{~S}\right]$

$\mathrm{K}_{\mathrm{n}} \quad=$ Monod saturation constant for sulphate $\left[\mathrm{SO}_{4}^{2-}\right]$

In the $\mathrm{H}_{2} \mathrm{~S}$ inhibition term in Eq. [4], $\left[\mathrm{H}_{2} \mathrm{~S}\right]$ must be less than $\mathrm{K}_{\mathrm{I}, \mathrm{j}}$ otherwise the inhibition term becomes negative; if this is encountered in model application the alternative non-competitive inhibition kinetics (Sötemann et al., 2005) will be considered. No reference is made in Kalyuzhnyi et al. (1998) to the exact $\mathrm{pH}$ inhibition formulation for $\mathrm{F}(\mathrm{pH})$ that was used in their model. Therefore, $\mathrm{pH}$ inhibition was excluded here initially. If required, when the SRB are integrated in the UCTADM1 model the $\mathrm{pH}$ inhibition function in the UCTADM1 model (non-competitive inhibition) could be used for the SRBs also. Hence, the SRB growth rate used was as given by Eq. [5], but with $\mathrm{F}(\mathrm{pH})$ excluded (Table 1). The approach to formulating the kinetic rates of Kalyuzhnyi et al. (1998) is the same as that used in the UCTADM1 model. Hence, only the $\mathrm{H}_{2} \mathrm{~S}$ inhibition term had to be added to the existing kinetic rate equations for the acidogenic, acetogenic and methanogenic bacterial groups in the UCTADM1 model when BSR was integrated with the UCT AD model.

\section{Endogenous decay kinetic rates}

Bacterial decay both in Kalyuzhnyi et al. (1998) and Sötemann et al. (2005) is described by first-order kinetics, and hence this approach was also followed here. The specific rate for bacterial decay is thus $=b_{j}\left[X_{j}\right]$ where $b_{j}$ is the specific decay constant for the bacterial population concerned, $X_{\mathrm{j}}$, Table 1 .

\section{Values for constants}

Values for the stoichiometric and kinetic constants for the SRBs were taken from Kalyuzhnyi et al. (1998), and are listed in Table 4.

\section{Aqueous chemistry and physical processes}

The BSR processes described above both produce and consume weak acid/base species, and hence these and the associated weak acid/base chemistry required inclusion in developing a kinetic model for BSR. Further, the compound $\mathrm{H}_{2} \mathrm{~S}$ is produced and the compound $\mathrm{H}_{2} \mathrm{CO}_{3}{ }^{*}$ is produced as well as consumed. Both these compounds have physical gas exchange processes with the atmosphere, and therefore these processes were also included in the model.

\section{Aqueous chemistry}

The following acid/base systems were identified as having direct relevance to BSR:
1. Water
$\mathrm{H}^{+} / \mathrm{OH}^{-}$
2. Ammonia
$\mathrm{NH}_{3} / \mathrm{NH}_{4}^{+}$
3. Carbonate : $\mathrm{H}_{2} \mathrm{CO}_{3}{ }^{*} / \mathrm{HCO}_{3}{ }^{-} / \mathrm{CO}_{3}{ }^{2}$
4. Acetate: $\mathrm{HAc}^{2} / \mathrm{Ac}^{-}$
5. Propionate : $\mathrm{HPr} / \mathrm{Pr}$
6. Sulphate : $\mathrm{H}_{2} \mathrm{SO}_{4} / \mathrm{HSO}_{4}^{-/} / \mathrm{SO}_{4}^{2-}$
7. Sulphide : $\mathrm{H}_{2} \mathrm{~S} / \mathrm{HS}^{-} / \mathrm{S}^{2-}$

Of these acid/base systems, 1 to 5 already have been included in the methanogenic UCTADM1 model, whereas 6 and 7 have not (Sötemann et al., 2005). Accordingly, for 1 to 4 the compounds and processes were taken unmodified from Table 1 in Mosvuto et al. (1997) and for 5 (propionate) this was taken unmodified from Table 2 in Sötemann et al. (2005). For 6 (sulphate) the dissociation reactions are as follows:

1) $\mathrm{H}_{2} \mathrm{SO}_{4} \Leftrightarrow \mathrm{HSO}_{4}^{-}+\mathrm{H}^{+}\left(\mathrm{pK}_{\mathrm{H} 2 \mathrm{SO} 4 / \mathrm{HSO} 4} \approx 0\right)$

2) $\mathrm{HSO}_{4}^{-} \Leftrightarrow \mathrm{SO}_{4}^{2-}+\mathrm{H}^{+}\left(\mathrm{pK}_{\mathrm{HSO}^{-} / \mathrm{SO} 4} \approx 1.99\right)$

Sulphuric acid acts as a strong acid, and since the $\mathrm{pK}$ values for both the equilibria are so low $(\approx 0$ and 1.99$)$ and the $\mathrm{pH}$ range of the systems to be modelled is unlikely to be $<\approx 4$, it could be accepted in the kinetic modelling that the only sulphate system species of any consequence is $\mathrm{SO}_{4}^{2-}$. However, in the AMD to be treated, the $\mathrm{pH}$ values may be very low $(\mathrm{pH} \approx 2-5)$. This will influence the species distribution of the equilibrium Eq. [7] in the influent, and hence this equilibrium needed to be included in the model. Thus, the sulphate acid/base was treated as a monoprotic acid/base, with the single equilibrium reaction Eq. [7]. To model this chemical dissociation equilibrium reaction, the approach developed by Musvoto et al. (1997) was followed, viz. the kinetics of the forward and reverse dissociation reactions were modelled. This required the inclusion of 2 new processes (C48 for forward dissociation, C49 for reverse dissociation), and

\begin{tabular}{|c|c|c|c|c|c|c|}
\hline \multicolumn{7}{|c|}{$\begin{array}{c}\text { TABLE } 5 \\
\begin{array}{c}\text { Petersen matrix representation of the } \mathrm{HSO}_{4}^{-} \text {acid/base } \\
\text { dissociation processes }\end{array}\end{array}$} \\
\hline & Number $\rightarrow$ & & C7 & C30 & C31 & \\
\hline$\downarrow$ No & $\downarrow$ Process & Compound $\rightarrow$ & $\mathrm{H}^{+}$ & $\mathrm{HSO}_{4}^{-}$ & $\mathrm{SO}_{4}{ }^{2-}$ & $\downarrow$ Process rates \\
\hline $\mathrm{C} 48$ & \multicolumn{2}{|c|}{ Forward dissociation $\mathrm{HSO}_{4}^{-}$} & +1 & -1 & +1 & $\mathrm{~K}_{\mathrm{fHSO} 4}^{\prime}\left[\mathrm{HSO}_{4}^{-}\right]$ \\
\hline C49 & \multicolumn{2}{|c|}{ Reverse dissociation $\mathrm{HSO}_{4}^{-}$} & -1 & +1 & -1 & $\mathrm{~K}_{\mathrm{rHSO} 4}^{\prime}\left[\mathrm{SO}_{4}^{2-}\right]\left[\mathrm{H}^{+}\right]$ \\
\hline & & & $\mathrm{mol} / \mathrm{e}$ & $\mathrm{mol} / \mathrm{e}$ & $\mathrm{mol} / \mathrm{e}$ & \\
\hline
\end{tabular}




\begin{tabular}{|c|c|c|c|c|c|}
\hline \multicolumn{6}{|c|}{$\begin{array}{c}\text { TABLE } 6 \\
\begin{array}{c}\text { Petersen matrix representation of the } \mathrm{H}_{2} \mathrm{~S} \text { acid/base } \\
\text { dissociation processes }\end{array}\end{array}$} \\
\hline & Number $\rightarrow$ & C7 & C32 & P5 & \\
\hline$\downarrow$ No & Compound $\rightarrow$ & $\mathrm{H}^{+}$ & $\mathrm{H}_{2} \mathrm{~S}$ & HS- & $\downarrow$ Process rates \\
\hline $\mathrm{C50}$ & Forward dissociation $\mathrm{H}_{2} \mathrm{~S}$ & +1 & -1 & +1 & $\mathrm{~K}_{\mathrm{fH} 2 \mathrm{~S}}^{\prime}\left[\mathrm{H}_{2} \mathrm{~S}\right]$ \\
\hline \multirow[t]{2}{*}{ C51 } & Reverse dissociation $\mathrm{H}_{2} \mathrm{~S}$ & -1 & +1 & -1 & $\mathrm{~K}_{\mathrm{rH} 2 \mathrm{~S}}^{\prime}\left[\mathrm{HS}^{-}\right]\left[\mathrm{H}^{+}\right]$ \\
\hline & & $\mathrm{mol} / \mathrm{e}$ & $\mathrm{mol} / \mathrm{e}$ & $\mathrm{mol} / \mathrm{e}$ & \\
\hline
\end{tabular}

two new compounds, $\mathrm{HSO}_{4}^{-}(\mathrm{C} 30)$ and $\mathrm{SO}_{4}{ }^{2-}(\mathrm{C} 31)$, see Table 5. For 7 (sulphide) the dissociation reactions are:

1) $\mathrm{H}_{2} \mathrm{~S} \Leftrightarrow \mathrm{HS}^{-}+\mathrm{H}^{+}\left(\mathrm{pK}_{\mathrm{H} 2 \mathrm{~S} / \mathrm{HS}} \approx 7.1\right)$

2) $\mathrm{HS}^{-} \Leftrightarrow \mathrm{S}^{2-}+\mathrm{H}^{+}\left(\mathrm{pK}_{\mathrm{HS} / \mathrm{S}} \approx 17.4\right)$

Since the $\mathrm{pK}_{\mathrm{H} 2 \mathrm{~S} / \mathrm{HS}}$ is high (i.e. $\mathrm{S}^{2-}$ acts as a strong base) and the $\mathrm{pH}$ range of the systems to be modelled is unlikely to be $>\approx 10$, the sulphide acid/base system could be accepted to act as a monoprotic acid/base in the kinetic model with Eq. [8] only. Again, the approach developed by Musvoto et al. (1997) for acid/ base modelling was accepted. This required the inclusion of 2 new processes (C50 for the forward dissociation, C51 for the reverse dissociation), and two new compounds, $\mathrm{H}_{2} \mathrm{~S}(\mathrm{C} 32)$ and HS- $^{-}$(C33), see Table 6.

In Tables 5 and 6, from Musvoto et al. (1997) $\mathrm{K}_{\mathrm{r}}$ was given a very high value (of the order of $10^{7}$ to $10^{15}$ with time units dependent on the integration period), the exact value depending on the stability of the solution procedure. The value for $\mathrm{K}_{\mathrm{f}}$ was then determined from the relationship with the appropriate equilibrium constant $\mathrm{pK}$. This ensured that the dissociation reactions were effectively instantaneous, and that the concentrations of the species established were the equilibrium concentrations.

The phosphate weak acid/base system was not included in the stoichiometry for the SRB growth and decay processes (Tables 1, 2 and 3), but is included in the weak acid/ base chemistry model of Musvoto et al. (1997). This weak acid/base system also required inclusion in the BSR model, since this system may impact on the $\mathrm{pH}$ through buffering type effects depending on its total species concentration. The kinetics and stoichiometry for this system were taken directly from Musvoto et al. Including the phosphate weak acid/base system chemistry may require that the biological processes kinetic model (Table 1) be revised to include uptake of $\mathrm{P}$ for growth of SRB and release of $\mathrm{P}$ in death of these organisms. This will be evaluated in model application and validation.

In the kinetic model developed for BSR, mineral precipitation reactions (i.e. the third solid phase) have not been included at this stage. Hence, ion paring reactions which directly impact the precipitation (Musvoto et al., 1997) also have not included.

\section{Physical processes}

In BSR the compound $\mathrm{H}_{2} \mathrm{~S}$ is produced and the compound $\mathrm{H}_{2} \mathrm{CO}_{3}{ }^{*}$ is produced and consumed. The weak acid/base species $\mathrm{NH}_{3}$ is present and involved in the biological processes. All these compounds have physical gas exchange processes with the atmosphere in the reactor, and therefore these processes were included:
1) $\mathrm{H}_{2} \mathrm{CO}_{3}^{*} \Leftrightarrow \mathrm{CO}_{2}(\mathrm{~g})$ exchange, where $\mathrm{H}_{2} \mathrm{CO}_{3}{ }^{*}=\mathrm{CO}_{2}(\mathrm{aq})+\mathrm{H}_{2} \mathrm{CO}_{3}$
2) $\mathrm{NH}_{3}(\mathrm{aq}) \Leftrightarrow \mathrm{NH}_{3}(\mathrm{~g})$ exchange
3) $\mathrm{H}_{2} \mathrm{~S}(\mathrm{aq}) \Leftrightarrow \mathrm{H}_{2} \mathrm{~S}(\mathrm{~g})$ exchange

For gas exchange 1: $\left(\mathrm{CO}_{2}\right)$, this had been included in the UCTADM1 model (Sötemann et al., 2005, Table 2) and could be taken unmodified from this model, i.e. physical processes for dissolution (P6) and expulsion (P7), and associated compounds $\mathrm{CO}_{2}(\mathrm{~g})(\mathrm{P} 1)$ and $\mathrm{H}_{2} \mathrm{CO}_{3}^{*}(\mathrm{C} 3)$.

For gas exchange 2: $\left(\mathrm{NH}_{3}\right)$, in the UCTADM1 model it was accepted that the atmosphere acts as an infinite sink for $\mathrm{NH}_{3}$, and hence only gas expulsion required inclusion. This was accepted for the BSR model also, and hence the single expulsion process (P8) was included, with associated compound $\mathrm{NH}_{3}$ (aq) (C2 from weak acid/base chemistry), and could be taken unmodified from Sötemann et al. (2005), Table 2.

For gas exchange 3: $\left(\mathrm{H}_{2} \mathrm{~S}\right)$, this is not included in any of the models developed to date and hence required inclusion. Either of the approaches for $\mathrm{CO}_{2}$ or $\mathrm{NH}_{3}$ could have been followed. However, it was considered prudent to follow the approach for $\mathrm{CO}_{2}$ and include both expulsion and dissolution reactions, as the atmosphere in the sulphate reducing bioreactor may develop significant sulphide gas concentrations, i.e. the atmosphere can not be considered as an infinite sink. This required the inclusion of 2 new processes ( $\mathrm{P} 12$ for $\mathrm{H}_{2} \mathrm{~S}$ dissolution and $\mathrm{P} 13$ for $\mathrm{H}_{2} \mathrm{~S}$ expulsion), and two new compounds, $\mathrm{H}_{2} \mathrm{~S}(\mathrm{aq})(\mathrm{C} 32)$ and $\mathrm{H}_{2} \mathrm{~S}(\mathrm{~g})(\mathrm{P} 5)$, see Table 7.

In Table $7, \mathrm{~K}_{\mathrm{rH} 2 \mathrm{Sg}}$ equals the $\mathrm{K}_{\mathrm{La}_{\mathrm{H} 2 \mathrm{~S}}}$ for $\mathrm{H}_{2} \mathrm{~S}$, which possibly could be linked to the $\mathrm{K}_{\mathrm{La}_{-} \mathrm{O} 2}$ for oxygen, through the proportion-

\begin{tabular}{|l|l|l|l|l|}
\hline \multicolumn{6}{|c|}{$\begin{array}{c}\text { TABLE 7 } \\
\text { Petersen matrix representation of the } \mathrm{H}_{2} \text { S exchange } \\
\text { physical processes }\end{array}$} \\
\hline & Number $\rightarrow$ & $\mathrm{C} 32$ & $\mathrm{C} 33$ & \\
\hline$\downarrow$ No & $\downarrow$ Process Compound $\rightarrow$ & $\mathrm{H}_{2} \mathbf{S}$ dslvd & $\mathrm{H}_{2} \mathbf{S}(\mathbf{g})$ Gas & $\downarrow$ Process rates \\
\hline $\mathrm{P} 12$ & Dissolution of $\mathrm{H}_{2} \mathrm{~S}$ gas & +1 & -1 & $\mathrm{~K}_{\mathrm{rH} 2 \mathrm{Sg}}^{\prime}\left(\rho_{\mathrm{H} 2 \mathrm{~S}}\right)\left(\mathrm{K}_{\mathrm{H} 2 \mathrm{~S}}\right)$ \\
\hline $\mathrm{P} 13$ & Expulsion of $\mathrm{H}_{2} \mathrm{~S}$ gas & -1 & +1 & $\mathrm{~K}_{\mathrm{rH} 2 \mathrm{Sg}}\left[\mathrm{H}_{2} \mathrm{~S}\right]$ \\
\hline & & $\mathrm{mol} / \ell$ & $\mathrm{mol} / \ell$ & \\
\hline
\end{tabular}


ality of the diffusivities for $\mathrm{O}_{2}$ and $\mathrm{H}_{2} \mathrm{~S}$ (Sötemann et al., 2005; Musvoto et al., 1997). Even though BSR systems are not aerated and significant $\mathrm{O}_{2}$ is not present or input (and hence the actual $\mathrm{K}_{\mathrm{La} \_ \text {O2 }}$ is zero), linking the $\mathrm{K}_{\mathrm{La} \text { H2S }}$ to $\mathrm{K}_{\mathrm{La} \text { O2 } 2}$ would be advantageous because this indirectly links the $\mathrm{K}_{\mathrm{La}}$ values for $\mathrm{CO}_{2}$ and $\mathrm{H}_{2} \mathrm{~S}$. The requirement to link the $\mathrm{K}_{\mathrm{La}}$ of a gas to that of $\mathrm{O}_{2}$ as a reference gas is that the dimensionless Henry's law constant of the gas $>0.55$; for $\mathrm{H}_{2} \mathrm{~S}$, the Henry's law constant is 40.9 to 0.41 . Thus, a strong possibility exists that the $\mathrm{K}_{\mathrm{La}}$ for $\mathrm{H}_{2} \mathrm{~S}$ can be linked in a fixed relationship to the $\mathrm{K}_{\mathrm{La}}$ for $\mathrm{O}_{2}$. In model application to BSR systems, the $\mathrm{K}_{\mathrm{La} O 2}$ is calibrated which sets the values for $\mathrm{K}_{\mathrm{La}_{\mathrm{CO} 2}}$ and $\mathrm{K}_{\mathrm{La}-\mathrm{H} 2 \mathrm{~S}}$, but the system is not aerated with air (aeration process excluded, or switched off). This option will be explored in model application and validation.

\section{Integrating aqueous chemistry and physical processes with biological processes}

In the descriptions above:

- A mathematical model has been developed describing the stoichiometry and kinetics of the biological processes directly involved with BSR (Table 1)

- The compounds associated with the aqueous chemical and the physical processes have been identified

- The kinetics and stoichiometry for the new aqueous chemistry and physical processes introduced by BSR have been developed.

It remains for these various processes to be combined and integrated with the UCTADM1 model, to give an integrated kinetic model for BSR systems. This integration was done to give two model types:

1 BSR as the 'sole' biological processes consuming the shortchain fatty acids (SCFA) and $\mathrm{H}_{2}$ substrates (i.e. methanogenesis excluded)

2 Both BSR and methanogenesis are present in competition for the SCFA and $\mathrm{H}_{2}$ substrates

In both models the chemical and physical processes are common. For the aqueous chemistry, the relevant processes were extracted from the various sources as described above (ammonia, carbonate, phosphate, acetate, water from Table 1 in Musvoto et al., 1997; propionate from Table 2 in Sötemann et al., 2005; sulphate and sulphide from Tables 5 and 6 respectively here). Similarly for the physical gas exchange processes (carbon dioxide and ammonia from Table 2 in Sötemann et al., 2005; sulphide from Table 7 here). When methanogenesis was included (model Type 2), then the approach of Sötemann et al. (2005) to modelling methane was followed, in which methane was considered as very insoluble and, since it is not utilised in any of the processes, needed only to be included as a gas phase compound (i.e. methane is generated directly as a gas).

For the Type 1 model, since the substrate being considered is PSS, the bioprocesses generating the substrates for BSR need to be included. These were taken from UCTADM1 (acidogens - Processes D1 to D4; acetogens - processes D5 and D6; Tables 1, 3 and 4 and Eqs. [8] to [11] and [14] in Sötemann et al., 2005). These were combined with the SRB bioprocesses developed above and listed in Table 1 (propionate consuming SRB, processes S1 and S2; acetotrophic SRB, processes S3 and S4 and hydrogenotrophic SRB, processes S5 and S6). Integrating these bioprocesses with the chemical and physical processes gave a 'stand alone' integrated two-phase chemical, physical and biological processes model for BSR with PSS as substrate.
For the Type 2 model, additionally to the above the acetotrophic (clastic) and hydrogenotrophic methanogen-associated processes required inclusion. These were extracted from UCTADM1 (acetotrophic (clastic) methanogens - Processes D7 to D8; hydrogenotrophic methanogen - processes D9 and D10; Tables 1, 3 and 4 and Eqs. [12] to [13] in Sötemann et al., 2005). Integrating these bioprocesses with the Type 1 model above gave a complete two-phase chemical, physical and biological processes kinetic model for competitive methanogenic and sulphidogenic anaerobic digestion with PSS as substrate.

\section{Model calibration, verification and validation}

The kinetic model developed above was implemented in the computer program AQUASIM (Reichert, 1998). Currently, the model is undergoing calibration, verification and validation. This involves confirming mass balances and that the predicted behaviour conforms to that expected, determining kinetic and stoichiometric constant values from the literature and through model application, and simulation and comparison of predicted and measured results for experimental systems in the literature. For these purposes, the data set of Ristow et al. (2005) appears suitable; they operated a series of experimental lab-scale systems which were fed a mixture of PSS and sulphate, operated over a range of retention times and $\mathrm{pH}$ values, and determined COD; free and saline ammonia (FSA); short-chain fatty acids (SCFA); $\mathrm{H}_{2} \mathrm{CO}_{3}{ }^{*}$ alkalinity; and $\mathrm{pH}$ of the effluent stream; effluent sulphate concentration; and $\mathrm{CO}_{2}$ and $\mathrm{CH}_{4}$ gases in the gas stream.

\section{Conclusions}

An integrated two-phase chemical, physical and biological process kinetic model for competitive methanogenic and sulphidogenic anaerobic digestion with PSS as substrate has been developed. This model requires validation through application to experimental data sets. For this purpose, the data set of Ristow et al. (2005) appears suitable, and this validation exercise is currently being completed.

\section{Acknowledgements}

This research was supported financially by the Water Research Commission, National Research Foundation and the University of Cape Town and is published with their permission. Further, the authors would like to thank Kwezi V3 Engineers for affording $\mathrm{S}$ van Wageningen the opportunity and support to further her studies.

\section{References}

BATSTONE DJ, KELLER J, ANGELIDAKI I, KALYUZHNYI SV, PAVLOSTATHIS SG, ROZZI A, SANDERS WTN, SIEGRIST H and VAVILIN VA (2002) Anaerobic Digestion Model No 1. Scientific and Technical Report (STR) No 13, International Water Association, London.

CHRISTENSEN B, LAAKE M and TORLEIV L (1996) Treatment of acid mine water by sulphate-reducing bacteria: Results from a bench-scale experiment. Water Res. 30 (7) 1617-1624.

DILL S, CLOETE TE, COETSER L and ZDYB L (2001) Determination of the Suitability of Alternative Carbon Sources for Sulphate Reduction in the Passive Treatment of Mine Water. WRC Report No. 802/1/01 Water Research Commission, Pretoria, South Africa.

FURTER L (2005) Innovative wastewater management. J. Inst. Mun. Eng. S. Afr. 30 (2) 38-39. 
GREBEN HA and MAREE JP (2000) The effect of reactor type and residence time on biological sulphate and sulphide removal rates. Proc. WISA 2000 Bienn. Conf. Sun City, South Africa. June.

HAMMACK RW, EDENBORN HM and DVORAK DH (1994) Treatment of water from an open-pit copper mine using biogenic sulphide and limestone: A feasibility study. Water Res. 28 2321-2329.

HOLTZHAUSEN L (2005) Mine water treatment technology. Water and Sewage Effluent 25 (2) 24-25.

IZZETT HB, WENTZEL MC and EKAMA GA (1992) The Effect of Thermophilic Heat Treatment on the Anaerobic Digestibility of Primary Sludge. Research Report No W76. Department of Civil Engineering, University of Cape Town, Rondebosch,, South Africa.

KALYUZHNYI S, FEDOROVICH V, LENS P, POL LH and LETTINGA G (1998) Mathematical modeling as a tool to study population dynamics between sulphate reducing and methanogenic bacteria. Biodegration 9 (3-4) 187-199.

MUSVOTO EV, WENTZEL MC, LOEWENTHAL RE and EKAMA GA (1997) Kinetic based model for mixed weak acid/base systems. Water SA 23 (4) 311-322.

REICHERT P (1998) Concepts underlying a computer programme for the identification and simulation of aquatic systems (Aquasim 2.0).
Swiss Federal Institute of Environmental Science and Technology (EAWAG), CH-8600, Switzerland

RISTOW NE and HANSFORD GS (2001) Modelling of a falling sludge bed reactor using AQUASIM. Water SA 27 (4) 445-455.

RISTOW NE, SÖTEMANN SW, LOEWENTHAL RE, WENTZEL MC and EKAMA GA (2005) Hydrolysis of Primary Sewage Sludge under Methanogenic, Acidogenic and Sulphate Reducing Conditions. WRC Report No 1216/1/05. Water Research Commission, Pretoria, South Africa.

ROSE PD, CORBETT CJ, WHITTINGTON-JONES K and HART OO (2002) The Rhodes BioSURE Process. WRC Report No TT195/02 ISBN 186845892. Water Research Commission, Pretoria, South Africa.

SÖTEMANNSW, VAN RENSBURG P, RISTOW NE, WENTZEL MC, LOEWENTHAL RE and EKAMA GA (2005) Integrated chemi$\mathrm{cal} /$ physical and biological processes modelling Part 2 - Anaerobic digestion of sewage sludges. Water SA 31 (4) 545-568.

VAN RENSBURG P, WENTZEL MC and EKAMA GA (2001) Integrated Biological, Chemical and Physical Processes Kinetic Model for the Anaerobic Digestion of Primary Sewage Sludge. Research Report No W113. Dept. Civil Eng., Univ. of Cape Town, Rondebosch, South Africa. 